\title{
Making Anthropology Matter in the Heyday of Islamophobia and the 'Refugee Crisis': The Case of Poland
}

\author{
Michał Buchowski
}

DOI: 10.21104/CL.2016.1.03

\begin{abstract}
This paper addresses the issue of multiculturalism in Poland, with the reference point being Islamophobia and the attitude towards 'the Other', especially immigrants in Europe. It is argued that today's attitudes towards the Other result from the most recent history, marked by the interwar, wartime and postWWII nationalisms, seven decades of a relative ethnic and cultural homogeneity of society, recent migration trends in Europe, the current 'refugee crisis' and worldwide spreading of a fear of terrorism, overwhelmingly bolstered by the media. These phenomena are scrutinized by referring to the example of Muslims living in Poland. An appeal for anthropological action in the social and political domain informed by expert knowledge is advocated.
\end{abstract}

Keywords islamophobia, migration, tolerance, multiculturalism, anthropological engagement.

Contact Prof. Michał Buchowski, Ph.D., Department of Ethnology and Cultural Anthropology, Adam Mickiewicz University, ul. Umultowska 89D, 61-614 Poznań, Poland, and European University Viadrina, Frankfurt/ Oder, Deutschland; mbuch@amu.edu.pl.

Jak citovat / How to cite Buchowski, Michał. (2016). Making Anthropology Matter in the Heyday of Islamophobia and the 'Refugee Crisis': The Case of Poland. Český lid 103, 51-67. doi:http:// dx.doi.org/10.21104/CL.2016.1.03 
In memory of Czesław Robotycki, a decent man and courageous anthropologist

\section{Introduction}

Czesław Robotycki asked a crucial question about the future of Polish multiculturalism and the fate of immigrants in the country - 'Poland is facing a fundamental problem: whether we will have fellow citizens, or only guests in the country' (2010: 111). Now, in the middle of the so-called refugee crisis of 2015-2016, we can push the question even further: Whether we will treat 'the Other' as enemies and a threat to our social order, or as fellow humans and citizens. These questions force us to think about what should be done for the society to function in the modern world of mobile people. This issue is a fundamental one for anthropologists, not only because of their traditional interest in cultural differences and intergroup relations but also because of the discipline's ethos of prohibiting discrimination against individuals and groups on account of their biological, social or cultural characteristics. This question also concerns the legal but first and foremost the 'mental constitution' of Polish society as well as other Central European and European societies, and, more broadly, the 'structure of feeling' of Europeans: a set of perceptions, ideals and values held by a particular group of people living in a certain time and place (Williams 1977: 128-135); those 'meanings and values as they are actively lived and held' (Williams 1977: 132).

Understanding modern nationalism is fundamental in this context. The initially emancipatory force of nationalism, which led to the liberation of various societies in the region, transformed into something that Louis Dumont calls 'German ideology', a horrendous hybrid of crude Darwinism transposed from the individual to the national level. This ideology legitimized the unrestricted right to ethnic cleansing, the fight for Lebensraum, and genocide of all those considered enemies. Thus, modern history has not been favourable to the inherited multi-ethnic and multi-religious traditions of the Commonwealth of Poland and Lithuania, which lasted until 1795. The birth of nationalistic ideas in the 19th century and their dominance in the 20th, reaching an apogee during World War II, changed Poland into an ethnically and religiously homogeneous country. The Communist authorities, sharing the ideology of national unity as a political virtue, took great pains to 'repatriate' (1944-1956), assimilate (1956-1989), and 'export' (1970-1980) the remaining minorities (cf. BuchowskiChlewińska 2012: 346-348). After World War II, minorities appeared in the propaganda only at times when problems with imaginary enemies - bandérivtsi, Zionists, or German revisionists - were being solved. The cultural and ethnic monochrome was paired with attempts to carry out a social uravnilovka (a topdown enforcement of uniformity) in the name of ideological equality and justice. This was supposed to be realized through activities propagating secularity, 
aimed at the disappearance of religion, hence also of the religious minorities. The goal of this Communist Gleichschaltung, like the Nazi one, was the removal of pluralism. Contrary to the postcolonial superdiversity (Vertovec 2007) that emerged in many European countries in the post-WWII and postcolonial period, I argue that it was superhomogeneity that appeared as the consequence of postsocialism in Poland and some other Central European countries.

This historical contingency caused ethnic and religious minorities to become absent from public discourse, except for the moments of 'conflicts with the enemies of the Polish People's Republic', a phrase often used in official propaganda. According to Robotycki (2010: 109), the minorities existed in the social consciousness only as ethnographic curiosities. While in reality the situation is somewhat more complex, I have to agree with this observation in general terms. It is within the framework of this homogeneity of Poland that racism and xenophobia perpetually re-emerge, fusing with the desire to impose one single legitimate world view and moral standards. Meanwhile, Poles' approach towards fellow citizens whose ethnic identity is other than Polish, and religions other than Catholicism, is a fundamental issue for the constitution of social life. This framework also directly affects attitudes towards immigrants, and refugees in particular. In this respect, I argue that anthropologists should not remain passive and should engage in social pedagogy. Facing racial and xenophobic practices head on is, in my view, a litmus test for the decency and social courage of anthropology and anthropologists in contemporary Europe.

Many Polish national historians like to instil a belief in the 'eternal tolerance' of Poles. Meanwhile, the history of this tradition described by such leading specialists on the subject as Janusz Tazbir shows how this attitude was reduced in the first Rzeczpospolita (Republic) (Tazbir 1967; 1973; 1980) and evaporated in the 19th century, the age of nationalism. No relation between the historical tolerance in the Republic of Nobles and the views of contemporary Poles can be traced besides the myth of the nation's inborn predisposition to tolerance (Buchowski - Chlewińska 2012: 360). Instead, it would be wiser to trace the roots of the attitudes towards the Other in the most recent history, contemporary social relations in Poland, Europe and worldwide, and overpowering media reports. In this article, my starting point for further remarks regarding anthropological engagement will be the account of 'Polish tolerance' through the prism of attitudes to Muslims living in Poland as well as purely media-made image of Muslims looming on the horizons of Europe.

Fundamental to understanding anti-Islamic attitudes in Poland is the fact that we are dealing with intolerance towards a group with which most people have had no immediate, daily contact, simply because they are so few and so invisible. The lack of acceptance of Muslims living in Poland, a 'religiously and culturally distant' group, is thus to some extent similar to the anti-Semitism present both in Polish folklore (cf. Cała 2005; BanasiewczOssowska 2007; Tokarska-Bakir 2008) and in contemporary public discourse 
and everyday politics. Włodzimierz Borodziej aptly remarked that 'there is no "Jewish question" in Poland. We deal with a problem of anti-Semitism whose vitality proves the well-known truth: anti-Semitism is the problem of anti-Semites' (2001: 67). Similarly, I will try to show that Polish anti-Islamism is the problem of the anti-Islamists. In other words, it is not Muslims who call into question 'Polish tolerance' in the light of officially accepted EU standards. As I will try to show, this tolerance is in fact limited merely to the groups perceived as culturally assimilated to the national mainstream for a long time or ready to succumb to assimilation. Only groups ready to accept their subordination to the majority in the material and symbolic relations of power and dominance are tolerated.

On the one hand, Polish 'anti-Islamism' is historically conditioned. The image of the country as the historical bulwark of Christianity is still popular. The Battle of Vienna in 1683, in which the Polish king Jan III Sobieski played a decisive role in defeating the Ottomans, is one of the most popular stories in the national mythology. On the other hand, anti-Islamism is a correlate of the spectre of the threat of radical and violent Muslims, fear of terrorism, which is widespread in the West. In the most recent 'refugee crisis', which has so far reached Poland only hypothetically - through media coverage and public debates - these two conditions are intertwined and demonstrated in a set of shocking, upsetting, even horrifying practices.

\section{Muslims in Poland}

In a highly homogeneous country, especially on the ethnic and religious level, being a Muslim is a distinctive feature of one's identity. There are at least five groups of Muslims in Poland. One of them is the Polish Tatars, living within the borders of contemporary Poland for centuries; another is old newcomers from the East, arriving here between the end of the 18th century and World War II, including those fleeing revolutionary and post-revolutionary Russia many members of those two groups have Polonized; the third group consists of immigrants mainly from Arab countries who came to Poland in the 1970s, the majority of them male students who married Polish women and settled in the country; the fourth group would be the new Muslims, refugees from exYugoslavia, especially from Bosnia and Hercegovina, political asylum seekers from Afghanistan, Pakistan, Chechnya and Syria (Marciniak 1997: 353259; Rykała 2011: 331-334; Kubicki 2006: 137-148), as well as investors and entrepreneurs, such as Turkish people who often open restaurants and bars in Poland (cf. Adamowicz - Kochaniewicz 2012: 116-127; Buchowski 2014). The fifth group is constituted of Polish converts to Islam, largely ignored in the analyses of Polish Muslims.

For the purposes of this article, a discussion on anti-Islamism in Poland should take into account the existence of two basic categories of Muslims: the 
historical ones, i.e. Tatars, and newer Muslims who arrived in Poland in the last century, especially the last few decades. Those two groups have a different legal status. Tatars are an officially recognized ethnic minority (in the 'Act of 6 January 2005 on national and ethnic minorities and on the regional languages' [Ustawa o mniejszościach narodowych $i$ etnicznych oraz o języku regionalnym $\left.{ }^{1}\right]$ ), while the latter are seen as 'incomers', even if they have Polish citizenship or permanent residence. In popular terminology they would be described as immigrants, and many among them as second-, third- or even fourth-generation immigrants. The former are subjected to the system that, following Agnieszka Pasieka (2015), I call hierarchical pluralism (Buchowski 2014). Tatars are incorporated and subsumed in the national system and are tolerated because they became part of the normative order set by the dominant group of Poles. While the Polish Tatars are Muslims and the majority of Poles are aware of their presence in the country, they perceive them as part of the Polish cultural landscape. They also function as witnesses and proof of the mythologized tradition of Polish tolerance and multiculturalism. However, it is important to note that newer Muslims outnumber Tartars.

\section{$\operatorname{Tartars}^{2}$}

Polish Tatars are the descendants of the Crimean Muslims who had been settling in the Grand Duchy of Lithuania since the 14th century. In fact, there are very few of them today - only 1916 according to the census from 2011, where 1,000 declared their Tatar identity as their primary one (665 as the only one) and 916 as their secondary one (Ludność... 2012: 261). They live all around the country, but the biggest centres are in the villages of Bohoniki and Kruszyniany in Podlasie (north-east Poland), and in Białystok, Warsaw, Gdańsk, and Gorzów Wielkopolski (Chazbijewicz 2010: 296). After centuries they have lost their language and accepted many Polish customs and share the lifestyle of their neighbours. Their religious writings are often a mixture of the Polish, Belarusian and Arabic languages. As Selim Chazbijewicz writes,

'...since the 16th century we can talk about a complete language assimilation. Since then, Tatar identity has been formed by Islam and the broadly understood religious culture, to the extent that the names "Tatar" and "Muslim" have come to be understood as synonyms' (2010: 301).

1 http://mniejszosci.narodowe.mac.gov.pl/mne/prawo/ustawa-o-mniejszosciac/tlumaczenia/6490, Tlumaczenia-Ustawy-o-mniejszosciach-narodowych-i-etnicznych-oraz-o-jezyku-region.html 
Under these circumstances, religion has become the mainstay of Tatar identity for the well-assimilated group. However, many Tatars married Christians, which often led to them ceasing to practise Islam. Therefore, actual assimilation with the dominant society deepened (Chazbijewicz 2010: 288-304). Their loyalty towards the state seems unequivocal, and 'Poland has become both a private and ideological fatherland for Tatars' (Warmińska 1997: 225). One can therefore say that the factors used by Tatars for their self-identification are limited to religion, religiosity and associated customs, as well as a mythical attachment to a certain historical community, while they also share a number of cultural features with the Catholic and Orthodox people around them.

\section{'Newer Muslims' in Poland}

The majority of 'newer Muslims' are former students of Arabic descent who settled in Poland as well as professionals, businessmen and entrepreneurs, diplomats, refugees and asylum seekers. The size of this group is estimated at around 20,000-30,000 people. In the national census from 2011 one can only find information about the national groups coming from countries where Islam is a dominant religion (Ludność... 2013: 262-264). Altogether their number is not higher than 10,000. Some declared exclusively non-Polish identity (e.g., Arabic, Turkish or Iranian), and many declared twofold identity (Polish and Arabic, or Arabic and Polish, etc.). Statistical data alone indicate that, including those self-identifying as Tatars, one can count less than 12,000 Muslims in Poland. There are also people of nationalities not historically identified as Muslim who are converts, but their number is only vaguely estimated at 3,0005,000 (Kubicki 2006: 143). It is hard to ascertain the number of self-declared Muslims, since the category of Muslim does not appear at all in the section on religious affiliation in the 2011 census (Ludność... 2013: 99-101). Moreover, the census does not include immigrants, asylum seekers or diplomats. Thus, we have to rely on estimates. According to Kubicki (2006), there are approximately 20,000 Muslims in the country, while Radosław Stryjewski gives a figure of around 40,000 (2011: 56). Even if we accept the number of Polish Muslims at the level of 30,000 , this is merely $0.079 \%$ of the country's population. ${ }^{3}$ In relation to other European countries like Germany, France or the Netherlands where Muslims are counted in millions and their proportion in the population often exceeds 5\% (cf. Gajlewicz-Korab 2011: 31), in demographic terms the phenomenon of Muslims is indeed almost non-existent in Poland.

One more factual remark is appropriate here. Until recently, well over 80,000 Muslim war refugees from Chechnya were received in Poland in this

3 For instance, in France this is 5.5\% of the population, in Holland - 4.3\%, in Germany - 3\% ('Biuletyn Migracyjny', 2006, no. 5, p. 1). Much higher numbers (after Tribalat [1995]) are given by Katarzyna Gajlewicz-Korab, respectively for France - 7-8\% (4-5 million), Holland - 5.8\% (945 thousand) and Germany - 3.4\% (3.2 million) (Gajlewicz-Korab 2011: 31). 
century. However, most of them stayed here temporarily, either on their way to Western Europe and the Czech Republic, or before returning to the Russian Federation (Włoch 2009: 60-62; Stryjewski 2011: 149-150). It is estimated that only 7,000-8,000 of them stayed in the country (Zuchowicz 2015).

Muslims have been recognized by the Polish authorities as a religious group with rights, and the first Muslim Association was officially acknowledged in 1936. Today, they are organized into several religious and cultural associations, which represent their various religious and cultural traditions (Stryjewski 2011: 71). While it is true that there are no Muslim schools, rooms in public schools are sometimes rented for religious education. Conflicts regarding the wearing of a headscarf are very rare (Włoch 2009: 60) and there are no restrictions in this matter. Until the current 'refugee crisis', Muslims had not been as interesting a subject for the media as in the countries where they comprise larger groups. Until the beginning of 2015 one could observe 'indifferent tolerance' towards them in Poland. However, occasional conflicts immediately stirred up fears and emotions, and triggered the re-emergence of stereotypes. I will now scrutinize three examples shedding some light on the problem of Polish tolerance and then move to the recent eruption of anti-Islamism.

\section{Phantom Islamophobia - three cases}

\section{Historically inherited anti-Islamism}

At the turn of the 16th and 17th century, anti-Islamic expressions were practically unknown in the Polish language, and Tatars were not discriminated against, at least on a religious basis (Włoch 2009: 59). Nevertheless, in the years following September 11, 2001, an aversion towards Islam started to become widespread. The historic image of Islam as a threat to the European civilizational identity and even to people's physical safety corresponds with the old Christian attitude to Islam as a rival and a sinister religion. As a result - according to the surveys conducted in Poland by Centrum Badania Opinii Społecznej-CBOS (Public Opinion Research Centre) - for a number of years Muslims have been the most negatively perceived group in the country next to the Roma minority; more than half of those questioned expressed disapproval towards them. The acceptance of the Roma has grown to 15\% since the mid-1990s; simultaneously, hostility towards 'Arabs' - who are often identified with 'Muslims' - remains at a high level and grows during debates on terrorist attacks or 'Muslim violence' witnessed in countries with large Muslim populations (Centrum... 2007; 2010). As Katarzyna Górak-Sosnowska remarked a decade ago, "the word "Islam" often functions next to the word "terrorism", which leads to inseparable combinations like "Islamic fundamentalism", "Islamists", "Islamic radicals" and, last but not least, "Islamic terrorism”' (2006: 159-160). Similarly, by referring to opinion polls (carried 
out by TNS OBOP [2001]), Agata Marek wrote that 'Answering the question "What do Poles associate the word Islam with?", two thirds answered neutrally - "Islam is associated with religion". However, almost all the other answers were negative - associating Islam with "war and terrorism", "war", "with Osama bin Laden", "with fundamentalism and fanaticism", "with aggression and violence", "with poverty and backwardness", and "with the Taliban". Only two out of every hundred people had positive connotations - associating Islam with oriental and Arab culture.' (2008: 38)

\section{Religious symbols}

a) Minaret/cultural centre construction in Warsaw

As in many places in Europe, the building of non-Christian religious structures stirs up protests. Attempts to erect mosques are especially contested. At present, there are five mosques in Poland. Two are owned by the Tatars in villages close to the Belarusian border. There is a mosque in Gdańsk, erected in the 1980s, the only one in the country with a visible minaret. The two other mosques, in Warsaw and in Poznań, are in fact villas converted into mosques.

The Muslim League, which brings together immigrants who are mostly from Arab countries, initiated the construction of the Centre of Muslim Culture (Stefaniuk 2010: 180). It is supposed to comprise of a mosque, a library and a meeting place, and fulfil many functions - popularizing Islamic culture, performing charity activities and operating as an exhibition space. This represents a considerable investment, sponsored by a private investor from Saudi Arabia. This initiative immediately met with objections. A protest was organized by an association based in Wrocław, 'Europe of the Future' (Stowarzyszenie Europa Przyszłości), which feared the emergence of Araboeuropa, 'Arabic Europe'. The demonstration was held in front of the construction site on 27 March 2010. The protesters, numbering 50, claimed that the Centre was sponsored by radical powers linked with Wahhabi Islam, known in some 'regions because of its military or even terrorist activities' (Machajski 2010). The sinister posters 'Stop the mosque in Warsaw' (Stop meczetowi $w$ Warszawie) displayed in the capital by the association showed a black silhouette of a person in a burqa, with minarets resembling bayonets in the background (Jędrusik 2010). Opponents organized a counter-protest and the discussion then continued on internet forums, with the majority of opinions expressing absolute disapproval of Islam, and especially its presence in Poland.

b) Joanna Rajkowska's 'Minaret Project' in Poznań

A well-known artist proposed an art installation: transforming the rather short chimney of an old paper factory in Poznan - located near an old, nonfunctioning synagogue - into a minaret. She had a clear goal: 
'To force us to talk about problems which we are silent about. About Islam, the position of women in that culture, about religion, about living with Muslims. I want to broaden Poznan's perspectives. For years I have been calling for diversity in our white, homogenous and Catholic society.' (cited in Korotko 2009)

Despite initial approval from the city authorities and efforts made by artistic and liberal circles, the idea has never been realized. The authorities represented by the deputy responsible for culture - as the artist put it - 'danced a counter dance'. In explaining their unfavourable judgement and negative decision, the Competition Jury stated:

'We consider the realisation of the project $a$. is culturally alien, $b$. disturbs the view of the cathedral and the former synagogue, c. can be perceived as a religious provocation, $d$. can be perceived as an attempt to ridicule the religious symbol - minaret - by installing it on an old industrial chimney, e. has no artistic qualities which would make it suitable for the cultural programme in the city of Poznań.' (cited in Wachowska-Kucharska 2011)

Arguments justifying the decision of the Competition Jury referred to different aspects of the project. First of all, the cultural strangeness of the project was emphasized - it was portrayed as something wicked. If that was so, then the presence of kebab shops, sushi restaurants and Chinese bars could have been questioned too. Yet those do not seem to bother anyone. Strangeness is a relative term here, because Islam has been present in Poland for centuries, as the example of the Polish Tatars and their legal and social status as described above clearly shows. The next, aesthetic argument refers to the issue of the perspective and other sacral buildings visible nearby, including the old, nonfunctioning synagogue (Kolbuszewska 2006). Yet we could reply by saying that it was precisely the juxtaposition of different religious symbols that the artist proposed. The project was also called a provocation, directed at the very sensitive religious sphere. One may presume it was the dominant majority's religious feelings which would have been offended. The argument stating that the minaret would insult Muslims was not justified, because their representatives in the city supported the initiative (Wybieralski 2009). Similarly, the final argument claiming that the project does not suit the artistic programme in the city is untenable: the organizers of the internationally famous Malta Festival that has taken place annually in Poznan for years made efforts to realize the project. It seems it was the resistance of conservative religious cir- 
cles and indignation expressed on internet forums ${ }^{4}$ which induced the authorities to give up on the idea. The competition was just a tool used to execute a decision made under pressure.

The content of the opinions expressed was difficult to accept, not only from the standpoint of political correctness, as guaranteed by the law, but also of decency and respect for others, in this case the Muslims. ${ }^{5}$ One journalist summed it up as follows:

'And so it has started: fierce discussion on internet forums, the first protest letters. Rajkowska is being accused of promoting Islam, religious provocation and wasting public money. In the statement against the minaret we read that it is Islam's Trojan Horse, which will help Muslims in their expansion in Poznań. 'The minaret is a symbol of Islam's dominance and the dauntless/uncontrollable pride of its believers. And mosques are breeding grounds for terrorists'.' (Korotko 2009)

\section{The 'refugee crisis' and hatred of Muslims}

In February 2015, before the eruption of the 'refugee crisis', the conservative journalist Dominik Zdort, drawing on the authority of George Friedman of the Stratfor institute, began questioning the allegiance of the Polish Tatars. A common language and customs, he argued, should not blind us to the overwhelming power of religion. Therefore, he pondered how it is possible that over such a long period of time Tatars have not yet fully assimilated, and because they have not, we ['Poles' - M. B.] should treat them with caution. He expressed his hope that security agencies would vet them, and the state should even be prepared to deport them. He was just uncertain as to the location to which they should be deported (Zdort 2015).

With the rise of the 'refugee crisis', the radicalization of language and views is striking. It is not necessary to go into detail because these are phenomena we witness every day with varying intensity across Europe. Football stadiums all over Poland are spaces for open racial and ethnic hatred. During a match between Lech Poznań and Podbeskidzie Bielsko-Biała which I attended as part of my ethnographic fieldwork for the project Football Research in an Enlarged Europe ${ }^{6}$ (12 September 2015), the spectators were confronted

4 See, for example, 'An appeal against the minaret' (Apel przeciwko minaretowi), in which one can read: 'Muslim expansion is progressing. Under the pretext of an art installation sponsored by Saudi Arabia and Hamas, Islamist radicals want to start constructing a mosque in Poznań. SAY NO.' www.europa21.pl/wiadomosc/11862-Apel_Przeciw_minaretowi_w_Poznaniu (viewed: 3 Jan. 2016) See: http://forum.gazeta.pl/forum/w,67,96952146,97027134,Islam_ nie_jest_otwarty_.html (19 Jan. 2016). 
with a enormous banner: 'To us it is obvious and simple, we do not want refugees in Poland' (To dla nas oczywiste i proste, nie chcemy uchodźców $w$ Polsce). Simultaneously, thousands of fans shouted hate slogans such as 'The Islamist, a dirty bastard, is no equal for us Poles. The whole stadium sings with us - refugees, fuck off' (Islamista, brudna kurwa, nam Polakom nie dorówna. Cały stadion śpiewa z nami, wypierdalać z uchodźcami). There was no consequential punishment by the authorities for individuals who were fully visible and identifiable, and only the leader of the Poznan soccer fans was recently brought to court. Equally offensive and equally unpunished slogans are shouted during demonstrations against the 'Islamization of Europe' or the 'Muslim invasion' (cf. Żytnicki 2015). Internet forums put virtually no limits on derogatory and vulgar anti-Muslim statements. 'Goat fuckers' ( $k o$ zojebcy), Pakis (ciapaki), bandits, terrorists, savages, and dirty scum are commonly used words. ${ }^{7}$ Even Church pulpits can serve as sites at which anti-Islamic attitudes are expressed. ${ }^{8}$

\section{Islamophobia without Muslims - how can it be explained?}

Let us now discuss the hostility towards Muslims. Apparently, many 'Poles have a strong sense of ethnic distance, and wherever they encounter an ethnic or national other, their standpoint is hardly tolerant' (Robotycki 2010: 109). As case studies have shown, this also applies to groups which Poles do not have any contact with on a daily basis; thus intolerance refers, in fact, to an imagined Other. Attempts to change the picture of the homogeneous society, the 'natural' state of 'Polish Poland', raise immediate concerns and reactions. Muslims encounter manifestations of xenophobia, which Renata Włoch refers to a 'phantom Islamophobia' (2009: 65). This is because negative attitudes towards Muslims do not result from personal experience, rivalry on the job market, or negative impressions from the use of public space. Instead, they represent an outcome of the power of symbols and associated fears: past visions of the threat from the infidels, the monopolistic position of the Catholic Church in association with Polishness, the strong influence of nationalist ideas and anti-Islamism fomented by the media in the West and within Poland. The threat is indeed a phantom one, the community of 'infidels' imagined, and the menace from the Muslims illusory. It does indeed resemble anti-Semitism - historical myths and modern-day Islamophobia feed the current representations which have a decisive effect on people's words and actions, including those of representatives of public offices.

Why is this happening? Another diagnosis proposed by Robotycki can be helpful here: 'The structure of the Polish culture is homogeneous (jednoimienna)

7 http://www.kibice.net/forum/viewtopic.php?f=3\&t=25424

8 http://wiadomosci.dziennik.pl/opinie/artykuly/501075,uchodzcy-jak-krzyzacy-biskup-

libera-jak-raz-wpuscisz-do-domu-obcego-mozesz-zgotowac-wielka-biede.html 
and has difficulties in becoming more open' (2010: 110). Historical and social conditions turned the homogeneity of the Polish society into a value. Strangeness seems to be something out of place (cf. Douglas 1966). The division between 'us' and 'them' has a crucial role in the cognitive organization of the world. Violation of this mental arrangement is seen as a threat. Some people are frightened by this, while others become guardians of the status quo. Together, in a xenophobic spirit, they reject everything which does not correspond to the broadly understood image of Polishness with Christianity at its core. In this constellation Islam is an arch-enemy, a fatal threat to the native tradition.

The other question concerns the ways in which society deals with newly arriving immigrants. Czesław Robotycki is rather pessimistic in this regard: for 'the newcomers who have recently started arriving in Poland...adaptation is difficult because of the type of culture, Poles' attitudes, the administrative barrier' (2010: 110). His views are confirmed by the actions of the Polish immigrant authorities, who severely restrict applications for citizenship, especially those coming from a Muslim background. The acceptance of Chechens was motivated by the state's politics towards Russia. Such generosity is not shown towards people escaping the war in the Middle East. Their cultural practices are perceived as obscure, strange, unwelcome and, last but not least, dangerous. In the mono-ethnic and mono-religious cultural and religious landscape of Poland, there is no place for Islam and the Muslims.

\section{Explaining and interpreting is not enough}

Identifying structural and cultural reasons for Islamophobia is our research duty. Sharing our findings and interpretations with the wider public is our pedagogical obligation. However, I am convinced it is not enough. Reacting to xenophobia and religious discrimination and all forms of cultural racism or cultural fundamentalism (Stolcke 1995) is also our moral and anthropological duty, especially now in the period of a tide of anti-Islamism and hatred toward others.

Scathing descriptions of Muslims deprive them of human features. In this respect Islamophobia is indeed reminiscent of anti-Semitism in interwar Germany. It was Victor Klemperer, a German philologist of Jewish origin, who in the 1930s grasped 'how a perverted language use will seduce even the initially innocent into complicity with genocidal policies and a politics of language that de-humanizes the other' (Baumann 2004: 43). And, as we all know, the Nazi use of language led not only to exclusion, but also to genocide. From the anthropological perspective, and not only from that perspective, Poland and the whole of Europe face a serious social and cultural problem.

I want to state in strong terms that this real danger has to be opposed head on. The reservations of some of my colleagues in Poland who insist 
that anthropology should focus on research and should not engage in politics seems ridiculous to me in this context. This is a different question than whether anthropology is political or not (Baer 2014), or whether it should be purely concerned with cognition or should be engaged (Brocki 2013). Even if anthropology for me is at its core political, I am prepared to take part in such intradisciplinary debates. However, in the current sociocultural-political context in Europe, anthropologists should use all their expertise to act against any form of discrimination.

Impelled by this motivation, I and a group of my collaborators decided to act. In the name of the Centre for Migration Studies at Adam Mickiewicz University in Poznań, an official statement entitled 'Poland! Your resistance toward refugees is shameful' ${ }^{9}$ was issued. The Centre organized a public demonstration attended by hundreds of participants in the city's main square under the slogan 'Refugees are welcome' on 13 September $2015 .{ }^{10}$ We anthropologists also participated in the first demonstration by Muslims in Poland against terrorism (Nyczka 2015). ${ }^{11}$ Migrant Info Point, an offshoot of the Centre, extends comprehensive help to migrants who have to deal with the state authorities and face many bureaucratic difficulties. Finally, the Polish Ethnological Society, of which I am currently the president, issued the following 'Position Statement' during its general conference in Lvov:

Position statement of the Polish Ethnological Society on expressions of xenophobia and intolerance in Poland

The Polish Ethnological Society, at its 91st General Assembly, held to commemorate the 120th anniversary of its founding in Lviv, would like to express its position on an issue that has been the subject of its members' research and educational activities since the organisation's inception - relations between people. Our decades-long professional activity and experience convince us of the need to take a decisive stand on this matter.

Over their history, the peoples of our region have been victimized, and individuals have suffered or lost their lives as the result of ideologically-driven intolerance and discriminatory practices directed against certain groups of people. Recent events associated with the so-called refugee crisis have sparked a wave of statements

9 http://www.cebam.amu.edu.pl/166-oswiadczenie-centrum-badanmigracyjnych-uam-w-sprawie-uchodzcow.html

10 http://www.federacja-anarchistyczna.pl/index.php/artykuly/dzialania-fa/ wielkopolskie/item/1016-poznań-wiec-,„uchodzcy-mile-widziani"-relacja

11 http://poznan.wyborcza.pl/poznan/1,36037,19262174,kto-wspierapoznanskich-muzulmanow-podemski-wasilewski-buchowski.html 
and actions that are incompatible with the values of humanism to which we adhere. Hate speech directed against people based on their race, ethnicity, religion or worldview has become widespread and acceptable. It is becoming rife at all levels of society, including, most regrettably, among opinion leaders, in the media, and in public places. This is being directed in particular at Muslims and national groups associated with this religion. We are dismayed by the widespread consent to these affronts on others by the citizens of our society, and at times, by organs of the state and the law. We warn that similar processes took place during the birth of a most horrible and openly dehumanizing system-fascism. These processes led to acts of genocide and ethnic cleansing. We need to prevent the dangers that arise from xenophobia, and for this reason, we call for efforts to combat it in all its forms, beginning with its expression in language and acts of verbal violence. We call instead for widespread expressions of social solidarity, a readiness to help the needy, openness and tolerance. We urge not only those in positions of authority, but also ordinary citizens, to take decisions and actions that represent concrete expressions of these values.

\section{Polish Ethnological Society}

Lviv, 25 September 2015

This leads us to the final conclusion about the role of anthropology in society when it comes to some questions which are vital for its functioning. Clifford Geertz (1986: 105), paraphrasing Friedrich Nietzsche, exclaimed: Anthropologie, meine frohliche Wissenschaft. No doubt it is so for many of us. However, at the same time it also has to be a responsible science that should really matter. And it really matters (not only) in times when crucial anthropological values are being questioned. Therefore, we should also exclaim, Anthropologie, meine verantwortungsvolle Wissenschaft!

February 2016 


\section{References}

Adamowicz, Anna - Kochaniewicz, Agata. 2012. Pracownicy branży gastronomicznej. In: Buchowski, Michał - Schmidt, Jacek (eds.): Migracje a heterogeniczność kulturowa. Na podstawie badań w Poznaniu. Poznań: Wydawnictwo Nauka i Innowacja: 116-127.

Baer, Monika. 2014. Między naukq a aktywizmem. O polityczności, płci i antropologii. Wrocław: Wydział Nauk Hisotrycznych i Pedagogicznych Uniwersytetu Wrocławskiego.

Banasiewicz-Ossowska, Ewa. 2007. Między dwoma światami. Żydzi w polskiej kulturze ludowej. Wrocław: Polskie Towarzystwo Ludoznawcze.

Baumann, Gerd. 2004. Grammars of Identity/Alterity. In: Baumann, Gerd Gingrich, Andre (eds.): Grammars of Identity and Alterity: A Structural Approach. Oxford: Berghahn: 18-50.

Borodziej, Włodziemierz. 2001. Poles and Jews in the 20th Century: The Persistence of Stereotypes after the Holocaust. In: Buchowski, Michał Conte, Edouard - Nagengast, Carole (eds.): Poland beyond Communism: 'Transition' in Critical Perspective. Fribourg: University Press: 61-70. Brocki, Marcin. 2013. Antropologia społeczna i kulturowa w przestrzeni publicznej. Problemy, dylematy, kontrowersje. Kraków: Wydawnictwo Uniwersytetu Jagiellońskiego.

Buchowski, Michał. 2014. Skala migracji a uprawianie antropologii: przykład imigrantów w Poznaniu. In: Dariusz Niedźwiedzki (ed.) Kultura, tożsamość i integracja europejska. Kraków: Nomos: 241-254.

Buchowski, Michal - Chlewińska, Katarzyna. 2012. Poland. In: Zapata-Barrera, Ricard -Tirnadyfallidou, Anna (eds.): Addressing the Issue of Tolerance in Europe: A Comparative Overview of 16 Countries. Barcelona: CIDOB: 345-370.
Centrum Badania Opinii Społecznej. 2007. Sympatia i niechęć do innych narodów. Komunikat z badań (M. Strzeszewski). Warszawa: CBOS.

Centrum Badania Opinii Społecznej. 2010. Stosunek Polaków do innych narodów (K. Wądołowska). Warszawa: CBOS.

Cała, Alina. 2005. Wizerunek Żyda w polskiej kulturze ludowej. Warszawa: Oficyna Naukowa.

Douglas, Mary. 1966. Purity and Danger: An Analysis of Concepts of Pollution and Taboo. London: Routledge.

Chazbijewicz, Selim. 2010. Tatarzy. In: Dudra, Stefan - Nitschke, Bernadetta (eds.): Mniejszości narodowe i etniczne w Polsce po II wojnie światowej. Kraków: Nomos: 288-304.

Geertz, Clifford. 1986. The Uses of Diversity. Michigan Quarterly Review 25: 105-123.

Gajlewicz-Korab, Katarzyna. 2011. Obraz muzułmanów we Francji w tamtejszych tygodnikach opinii. Warszawa: Instytut Dziennikarstwa Uniwersytetu Warszawskiego.

Górak-Sosnowska, Katarzyna. 2006. Co wiemy o islamie? Polacy wobec islamu i muzułmanów. Teofil. Pismo Kolegium Filozoficzno-Teologicznego Dominikanów 2, 24: 149-164.

Jędrusik, Milada. 2010. Wrogowie meczetu w stolicy. Gazeta Wyborcza, 25 March. [2016-01-19] Retrieved from: http:// wyborcza.pl/1,76842,7698816,Wrogowie_ meczetu_w_stolicy.html.

Kolbuszewska, Daina. 2006. Czy poznańską synagogę można wyburzyć? Gazeta Wyborcza, 12 January. [2016-01-19] Retrieved from: http://wiadomosci.gazeta.pl/ wiadomosci/1,114873,3110371.html.

Korotko, Dariusz. 2009. Radość w Iraku, minaret w Poznaniu. Gazeta Wyborcza, 30 June. [2016-01-19] Retrieved from: http://wyborcza. pl/1,76842,6772584,Radosc_w_Iraku_ minaret_w_Poznaniu.html\#TRrelSST. 
Kubicki, Paweł. 2006. Kim są polscy muzułmanie? Teofil. Pismo Kolegium Filozoficzno-Teologicznego Dominikanów 2, 24: 137-148.

Ludność... 2013. Ludność. Stan i struktura demograficzno-społeczna. Narodowy Spis Powszechny Ludności i Mieszkań 2011. Warszawa: Główny Urząd Statystyczny.

Machajski, Piotr. 2010. Nie chcą meczetu w Warszawie. Gazeta Wyborcza, 24 March. [2016-01-19] Retrieved from: http://wyborcza.pl/1,76842,7694477, Nie_ chca_meczetu_w_Warszawie.html. Marciniak, Tomasz. 1977. A survey of Muslim minorities in Poland. Journal of Muslim Minority Affairs17, 2: 353-359.

Marek, Agata. 2008. Dlaczego boimy się islamu? In: Kosowicz, Agnieszka Marek, Agata: Muzułmanie i uchodźcy w polskim społeczeństwie. Warszawa: Stowarzyszenie 'Vox Huamna': 37-41.

Nyczka, Tomasz. 2015. W Poznaniu odbędzie się pierwsza w Polsce muzułamńska demonstracja przeciw terrorystom. Gazeta Wyborcza Poznań, 18 Nov. [2015-12-20] Retrieved from: http://poznan.wyborcza.pl/ poznan/1,36037,19210456,w-poznaniuodbedzie-sie-pierwsza-w-polscemuzulmanska-demonstracja.html.

Pasieka, Agnieszka. 2015. Hierarchy and Pluralism: Living Religious Difference in Catholic Poland. Basingstoke: Palgrave.

Robotycki, Czesław. 2010.

O wieloetniczności współczesnej Polski (antropologiczne zastrzeżenia etnografa). In: Kusek, Robert Sanetra-Szeliga, Joanna (eds.): W stronę nowej wielokulturowości I Towards a New Multiculturalism. Kraków: Międzynarodowe Centrum Kultury: 79-113.

Rykała, Andrzej. 2011. Mniejszości religijne w Polsce. Geneza, struktury przestrzenne to etniczne. Łódź: Wydawnictwo Uniwersytetu Łódzkiego.

Stefaniuk, Tomasz I. 2010. Islam i muzułmanie w Polsce / Islam and Muslims in Poland. In: Kusek, Robert Sanetra-Szeliga, Joanna (eds.): W stronę nowej wielokulturowości /
Towards a New Multiculturalism.

Kraków: Międzynarodowe

Centrum Kultury: 166-187.

Stolcke, Verena. 1995. Talking Culture: New Boundaries, New Rhetorics of Exclusion in Europe. Current Anthropology 36: 1-24. Stryjewski, Radosław. 2011. Integracja społeczna i gospodarcza imigrantów wyznania muzułmańskiego w Polsce. Raport z badań. Warszawa:

Fundacja "Ocalenie".

Tazbir, Janusz. 1967. Państwo bez stosów. Szkice z dziejów tolerancji w Polsce XVI i XVII wieku. Warszawa: Państwowy Instytut Wydawniczy.

Tazbir, Janusz. 1973. Dzieje polskiej tolerancji. Warszawa: Wydawnictwo Interpress.

Tazbir, Janusz. 1980. Tradycje tolerancji religijnej w Polsce. Warszawa: Książka i Wiedza.

TNS OBOP. 2001. Z czym kojarzy się Polakom słowo 'islam'. Warszawa: TNS OBOP.

Tokarska-Bakir, Joanna. 2008. Legendy o krwi. Antropologia przesqqdu. Warszawa: W.A.B.

Tribalat, Michèle. 1995. Faire France. Une grande enquête sur les immigrés et leurs enfants. Paris: La Découverte.

Vertovec, Steven. 2007. Super-diversity and its Implications. Ethnic and Racial Studies 30: 1024-1054.

Wachowska-Kucharska, Anna. 2011. Historia minaretu, który nie powstał. Res Publica Nowa, listopad/November. [2016-02-02] Retrieved from: http:// publica.pl/teksty/historia-minaretuktory-nie-powstal-5312.html.

Warmińska, Katarzyna. 1997a. Tatarzy polscy. Tożsamość etniczna i religijna. Kraków: Universitas.

Warmińska, Katarzyna. 1997b. 'Polskość' a 'tatarskość. In: Kempny, Marian Kapciak, Alicja -Łodziński, Sławomir (eds.): U progu wielokulturowości. Nowe oblicza społeczeństwa polskiego. Warszawa: Oficyna Naukowa.

Williams, Raymond. 1977. Marxism and Literature. Oxford: Oxford University Press.

Włoch, Renata. 2009. Islam in Poland: Between Ethnicity and Universal 
Umma. International Journal

of Sociology 39, 3: 58-67.

Wybieralski, Marcin. 2009. Awantura

o minaret w Poznaniu. Gazeta

Wyborcza, 1 July. [2016-01-19]

Retrieved from: http://wyborcza.

pl/1,76842,6772198,Awantura_

o_minaret_w_Poznaniu.html.

Zdort, Dominik. 2015. Dokąd deportować

Tatarów. Rzeczpospolita, 06 February. [2016-01-20] Retrieved from: http:// www.rp.pl/artykul/1177173.htm.

Zuchowicz, Katarzyna. 2015. Polska przyjęła już ponad 80 tysięcy Czeczenów i wciąż przyjmuje następnych. Czy komuś to przeszkadza? Na:temat.
[2016-02-05] Retrieved from: http:// natemat.pl/155107, polska-przyjelajuz-blisko-90-tysiecy-uchodzcowz-czeczenii-dzis-zostala-ich-tylkogarstka-bo-nie-chcieli-u-nas-zostac.

Żytnicki, Piotr. 2015. Narodowcy obrażają bezkarnie muzułmanów. Policja: konsultowaliśmy się z prokuraturą, nie dopatrzyła się przestępstwa. Gazeta Wyborcza - Poznań, 4 October. [2016-01-25] Retrieved from: http://poznan.wyborcza.pl/pozna $\mathrm{n} / 1,36037,18965961$, narodowcyobrazali-bezkarnie-muzulmanowpolicja-konsultowalismy.html. 
